\title{
Food and nutrition policies of Nordic countries: how have they been developed and what evidence substantiates the development of these policies?
}

\author{
Unni Kjærnes \\ National Institute for Consumer Research, PO Box 173, N-1325 Lysaker, Norway
}

\begin{abstract}
The present paper addresses the emergence and development of Nordic food and nutrition policies, with some reference to the types of nutrition policies characteristic of other North European countries. Nutrition programmes aimed at dietary change have a long history of public responsibility in several Nordic and North European countries. The extent of involvement, the orientation and (indication of) success have, however, varied considerably between countries. First, different types of policies are characterised by their choice of programmes and measures, e.g. information campaigns $v$. market regulation or catering and public services. Second, the distinctions are associated not only with programmes, but also with the status and validity of nutritional advice and dietary guidelines in public policy making. Third, when focusing on how and on what grounds the governments have developed nutrition policies, it is evident that while more or less the same participants and issues are involved, their roles and relationships may be different. In this case the role and involvement of nutritional expertise and scientific arguments in various countries will be discussed. Finally, nutrition policies may entail conflicts of interest, particularly when health concerns are confronted with food industry and agricultural interests. This situation is quite evident in the question of animal fat. The present paper addresses how these issues have been dealt with quite differently in various countries.
\end{abstract}

Nordic diets have in several respects developed in a more healthy direction. Vegetables, fruits, low-fat milk, low-fat spreads and cheese consumption has increased, while that of butter, whole milk and potatoes has decreased. Moreover, Roos et al. (1997) have described how diet-related health improved in Finland, Norway and Sweden between 1970 and 1995; in particular, cardiovascular disease mortality decreased.

Among the Nordic countries the understanding of nutritional problems has been quite similar, often also coordinated. The implementation of nutrition policy has, however, been quite diverse (Kjærnes 1985, 1997; Jul, 1988). Analyses of how and why such differences develop may contribute to an understanding of connections between the political and institutional situation, on the one hand, and the formulation of nutrition policy, on the other. The main question is how important is the institutional framework in determining the content of nutrition policies? The present paper addresses the emergence and development of Nordic food and nutrition policies, with some reference to the types of nutrition policies characteristic of other North European countries.

\section{Nutrition, interests and politics}

The promotion of nutrition policy is based on a belief in State involvement to solve what is considered to be a social problem. However, this belief in regulation is confounded by the liberal aim of sustaining the autonomy of the individual. This dilemma will influence the extent of State involvement and the application of different measures, such as information, fiscal measures and law enforcement. Social and historical studies have focused on two features of nutrition policies (Zebich, 1979; Aronson, 1982; Levenstein, 1988; Helenius, 1991; Mills, 1992; Holm et al. 1993; Jensen, 1993; Palmblad \& Eriksson, 1995). The first feature is the importance of different interests and their relative strength in the political process and in the organisation of the policy. The second feature is the position of expertise and the relationship between a policy defined by experts and individual freedom of action. Nutrition policy may be framed in several, quite diverging, ways. A basic conflict is linked to the distribution of food as a commodity, with the producer and supply side of the market, on the one hand, and 
consumers, the demand side, on the other. This conflict is not only associated with price, but also with the composition and quality of foods and that of the supply in general, as well as (access to) information. A nutrition policy may aim to get the market operating more effectively in relation to nutrition, it may protect the consumer against undue effects of market interests, or the policy may disregard these questions altogether. Other approaches to nutrition policy may focus on the distribution of income and conflicts in the labour market, or client relations in therapeutic or care-orientated services, including public catering. Different structures will influence the participants involved and the relationship between interests, and also the outcome in terms of organisation (Milio, 1990; Helsing, 1991). For example, nutrition policies have been defined in association with social policy and redistribution programmes, with health policy and with agricultural policy and food security (Kjærnes, 1996). The structure and the organisation will give quite different possibilities for action. By considering the historical development the background for, and consequences of, such differences can be discussed.

The approach 'historical institutionalism' implies an analysis of public and social institutions, how they shape the expression of interest of political participants and the power relationships between groups in society (Steinmo et al. 1992). Even if the articulation of interests and the understanding of problems may change with time, institutions will, as such, have responsibilities for how problems are expressed and how they are solved. This situation does not mean that political development is deterministic, but rather that it is possible to investigate the connections between the contents of a policy, its structural framework and political articulation as a dynamic process. By focusing on institutional continuity, it is possible to be aware of important changes and what has caused them. The establishment of a policy is a process involving several steps or elements, including: first, initiation of action and problem formulation; next, political processes ending with decisions about political goals, the establishment of special bodies and measures; finally, implementation as a third element. A policy is rarely established permanently; re-definitions, re-organisations etc. will take place, and the extent and time span may vary considerably for the various steps or elements.

A description of the institutional development within the area of nutrition is not a straightforward task, as knowledge is very fragmented. This process becomes even more difficult when it is necessary to focus on the relationship between interests. Such analyses have been made within several areas, with a particularly large comparative literature within welfare-state research. However, nutrition policy has not been included within this picture. The present review must therefore be considered as tentative and explorative, based mainly on secondary literature.

\section{The first establishment of nutrition policies}

While many descriptions of nutrition policies start in the 1970s, historical information is generally at least 50 years older. If the institutionalisation hypothesis is to be taken seriously, there must be an awareness of these early phases.
Historical studies have pointed to the emergence of nutrition policy as closely associated with the period of industrialisation, with the growth of cities, increasing social differentiation and changes in food supplies and distribution systems (Hirdman, 1983; Levenstein, 1988; Burnett, 1989). In Denmark, Sweden and Norway nutrition has been a part of hygiene-related measures, in the form of education and school meals, since the late 19th century (Statens Husholdningsraad, 1937; Hirdman, 1983; Seip, 1984). During the First World War the authorities in Sweden and Norway used nutritional expertise in connection with the supply crisis. The frame of reference was initially economic, i.e. to provide sufficient food for poor families. Throughout Europe the traditional orientation of the code of practice towards contentment and a simple way of life was reflected in estimates of needs that were generally very low (Jones, 1986; Kamminga \& Cunningham, 1995). The conflicts that eventually evolved had clear references to this means of defining nutritional problems, where the established expertise supported the authorities' restrictive social policy programmes. In a time period marked by economic crisis numerous unemployed and poor families lived on very low incomes. The traditional poverty support was increasingly regarded as being both insufficient and inappropriate. Inspired by a similar debate in the UK, Norwegian and Swedish critics argued that the support did not lead to the provision of a nutritionally-adequate diet, with sufficient vitamins and energy (Odin, 1934; Evang \& Hansen, 1937; Jones, 1986; Kjærnes, 1990). Moreover, critics stated that it was unreasonable that some of the population should have to subsist permanently on potatoes, skimmed milk, more or less rancid herring, and little else.

A new approach in the mid 1930s was initiated by demands for an expanded nutrition policy on a permanent basis. Norwegian nutrition policy was closely associated with the emerging welfare state (Esping-Andersen, 1990; Jensen, 1994). The 1938 report on the 'Nutrition Issue' by the Swedish Population Commission (Befolkningskommissionen, 1938), led by the famous economist Gunnar Myrdal, points in the same direction. Social inequalities associated with nutritional problems were used as important arguments for the State to be much more involved in welfare issues, especially among experts on the political left (Myrdal \& Myrdal, 1936; Evang \& Hansen, 1937). As mentioned earlier, nutrition may also be associated with conflicts in the food market. The between-war agricultural problems of surplus production and falling prices were particularly critical for the important dairy industry. Increasing unrest and political activity resulted in demands for increased regulation of the food market. The outcome was political coalitions between the respective labour parties and the agrarian parties, later emphasised as an important element in the establishment of the Scandinavian welfare state (Esping-Andersen, 1990). In Norway the coalition was particularly important, in that nutrition policy became synonymous with an alliance between farmers and workers, between city and countryside, with milk as a symbol (Jensen \& Kjærnes, 1997). With its strong association with science, nutrition also fitted well into the forms of regulation that became popular (belief in active governance, cooperation and expertise) in Norway as well as in Sweden (Hirdman, 
1990). Finnish doctors had been concerned with nutrition for a long time, and the situation reached a peak in the $1930 \mathrm{~s}$ (Riska, 1993). However, their concerns had a strictly natural science orientation. Discussion of welfare, distribution and public responsibility was less evident (Gustafsson et al. 1974). The agricultural crisis was handled with much more direct reference to the needs of industry, particularly in relation to exports. Danish agriculture, which was export orientated, was less concerned with State protection and the need for a policy for higher domestic prices (Pedersen et al. 1974). It is, therefore, not unexpected that the 'great' solution from Norway and Sweden had less success in Denmark. Agricultural support and welfare policy remained different projects, despite political alliances (Møller, 1994). It is more remarkable that nutrition could be used in Sweden and Norway to legitimise higher prices, when the end point was the understanding that nutritional problems were primarily related to the sections of the population that could not afford to buy nutritious foods.

The political activity was reflected in new institutions. In 1935 the Swedish Nutrition Council, a medical expert body, was established under the health authorities 'for issues related to public nutrition' (Befolkningskommissionen, 1938). In Finland an expert-based nutrition council was established in 1936, but here it was under the Ministry of Agriculture (Murcott \& Prättälä, 1993). Even in Norway an expert-based council was established in 1937 under the Ministry of Social Affairs. In Denmark the National Council for Home Economics was established under the Ministry of Internal Affairs in 1935 (Frandsen, 1937), one aim being nutrition education. The Nordic discussion on nutrition was not an isolated phenomenon. The League of Nations and the International Labour Organization had nutrition high on their agendas, with the combination of social- and marketing-related problems as their main focus. In 1937 The League of Nations recommended that member countries should formulate 'nutrition policies' and establish 'National Nutrition Committees' that should include nutrition expertise and representatives from the producers (Fridericia, 1937; McDougall, 1938). In 1946 the Norwegian National Nutrition Council was reorganised according to the recommendations of the League of Nations, with representatives from various industries and involved ministries, in addition to nutritional and economic expertise (Kjærnes, 1990; Haavet, 1996).

Nutrition-related activities in the 1930s involved more than advisory bodies. In Sweden the report on the 'Nutrition Issue' under the leadership of Myrdal (Befolkningskommissionen, 1938) had a considerable influence on subsequent efforts, particularly in relation to a school meal reform (to include all children) made in 1945 (Palmblad \& Eriksson, 1995). This reform was regarded as important for the improvement of the well-being of those in the population who were in most need, the view being that public services such as school meals could regulate consumption more efficiently than economic support. However, a 'double strategy' was emphasised, which included social reforms as well as educational efforts (Palmblad \& Eriksson, 1995). Finland was at that time marked by war and crisis, which resulted in food security issues dominating the agenda, and more long-term reforms were of less importance (Murcott \& Prättälä, 1993).
In Norway plans for improved nutrition were included in discussions of social political reforms, e.g. in the programme of the governing Labour Party. Even the service-orientated strategy had proponents, mainly among leading economists, but it was rejected by the Labour Party with particular reference to the individual's freedom of action (Kjærnes, 1990). However, education, in a quite paternalistic style, was important even in Norway, where it focused on the lack of knowledge and motivation among housewives (Evang \& Hansen, 1937). Nevertheless, the predominance of efforts that would stimulate production was evident in discussions on nutrition, in political debates and later in the National Nutrition Council, during and after the Second World War.

In Denmark there was no activity that pointed towards social political reforms similar to those taking place in Sweden and Norway (Statens Husholdningsraad, 1937), and economists were not involved in nutrition issues related to strong market regulation. As already mentioned, the political interests of the producers were reflected in a less regulation-orientated policy. As in Norway, there was also less focus on welfare services such as school meals, compared with Sweden (Møller, 1994). The outcome was less political 'space' for a nutrition policy with strong measures and legitimacy linked to strong policy sectors.

\section{Redefinition of goals in the 1970s and 1980s}

Nutrition policy was established in the Nordic countries as an area between welfare policy conflicts and conflicts related to the food market. The policy solutions diverged considerably, depending on how these conflicts were handled individually and the relationship between them. These models gave quite different political and institutional environments for dealing with the nutritional problems associated with coronary disease and fat intake that emerged in the post-war period. (The period between the First and Second World Wars has been described here as being central to the establishment of nutrition policies in the Nordic countries. However, for the work that followed in the post-war period, even the experiences from the war must be considered. A war will result in priority being given to special issues, particularly in relation to supplies and food security problems. It is also a general finding that temporary institutions, measures and alliances developed in times of war, and crisis may have considerable impact on later policies. There is, however, insufficient knowledge or space for a discussion of this topic here.) Nutrition-related health problems were quite similar in the Nordic countries (Jul, 1988). Nordic nutrition scientists were quite advanced, and in 1968 they agreed on a radical redefinition of nutrition recommendations (Lien, 1990). At this point, however, unity ends.

Since the end of the 19th century North European farmers have concentrated on the production of animal products that considerably increased the overall fat output. In addition, the margarine industry expanded. The consumption of animal and hardened fat increased, peaking towards the end of the 1950s. The suggestion in the late 1950s of a possible association between the high fat intake and the increasing incidence of CHD created political problems. 
From a status as essential foods, full-fat milk and butter became a nutritional problem. While poor nutrition up until then had been considered to be (at least partly) an economic problem, the predominant view was now that fat-related problems were not directly associated with income. Hence, the 'fat conflict' became less important for political debates focusing on welfare than the earlier nutrition-related issues.

Sweden has had a long tradition of public health education. Within this setting, measures were redirected quite early towards fat intake. A medical expert group under the social authority had already in 1971 initiated a campaign on diet and physical exercise. Nutrition was an issue of preventive health, mainly related to individual motivation. Its legitimacy seems to have been linked to extensive confidence in medical expertise and the universal Swedish educational project (Palmblad \& Eriksson, 1995); not so much nutrition as a policy or a 'good cause'. Organisationally, the main responsibility was given to the Swedish Food Authority, under the Ministry of Agriculture.

The Finnish nutrition policy had been institutionalised as an integral part of agricultural policy. The conflict between consumer interests and social democracy, on the one hand, and agricultural interests on the other, had for a long time been strongly politicised, with the consumers as the weakest party (R Helenius, unpublished results). It is therefore not surprising that reformulation of nutrition recommendations proved to be very difficult throughout the 1960s and 1970s, opposing as they did the interests of the farmers. Problems associated with the link between nutrition and agriculture were debated, but any attempts to change the organisation were abandoned. However, parallel to this situation, nutrition-related activities developed within other sectors, concentrating on child nutrition, a less controversial subject. Rather extensive measures were established that were linked to school meals and prevention in primary health care (Murcott \& Prättälä, 1993). The most important of these measures is the North Karelia Project, which was launched in 1972 and combined campaigns aimed at reaching the whole population and screening for high-risk groups (Roos et al. 2002).

In Norway it was soon evident that the fat-health issue challenged the legitimacy of the extensive subsidies to the dairy industry (Hansen, 1990). From being harmonious, the relationship between nutrition recommendations and agricultural interests became very controversial, a situation that was difficult for the consensus-based nutrition council to handle. What is special about the Norwegian situation is, however, that they did succeed in reformulating the coordinated food and nutrition policy after a few years. An important explanation seems to be the high political status of nutrition policy and its independent scientific and institutional basis. More specifically, the agricultural industry needed alliances in the mid 1970s in their attempts to extend public support. By once more combining nutrition and agricultural goals, nutrition recommendations were reformulated in a white paper, and approved by the parliament (Landbruksdepartementet, 1975). The main emphasis was placed on market regulation within the established system. Even if this achievement represented an important political success and much public attention, the outcome was ambiguous, with a moderation of nutrition goals and very limited formal influence (Hansen, 1990).

Nutrition policy continued to have very low priority in Denmark. No independent bodies had been established that could articulate the nutrition cause. Danish nutrition policy concentrated primarily on consumer education (administratively under the Ministry for Industry and Trade). This connection offered a weak basis for raising market- or welfare- and/or health-related issues. Moreover, there were no powerful professional groups to lobby for the new nutrition issues, and a long time passed before any consideration was given to problems related to fat. The issue appeared on the agenda in the early 1980s, primarily through the Danish Food Authority. The subject was controversial, primarily with reference to individual freedom of action rather than the role of the food producers. In 1984 parliament passed a resolution on a Danish nutrition policy, establishing also a nutrition unit within the Danish Food Authority. The primary strategy was still education and information, but with some concern also for food regulations and public catering. Furthermore, an institute for nutrition research had recently been established. However, political activity and public attention were limited. According to Holm et al. (1993), the producers succeeded in keeping food policy decisions within closed forums, in which nutrition advocates, with their weak organisational basis, had little power.

When comparing the Nordic countries, the political conflicts associated with the redefinition of nutrition policy goals seem at first greater in countries where the connection between food production and consumption was already subject to strong regulation, such as in Finland and Norway (Hansen, 1990; Murcott \& Prättälä, 1993). New nutrition problems that were not seen as a matter for either welfare measures or market regulation were easily turned into a question of influencing individual choice. In Sweden there were no dramatic confrontations between representatives of agriculture and others, seemingly giving a less problematic situation. At the same time, their focus restricted policy to school meals and education. Compared with the other countries, Danish food and nutrition policy appears to be much more liberal, by not considering market-related or welfare-related problems as arguments for increased public involvement.

\section{Recent changes: more explicit health goals and a turbulent market}

The past $10-15$ years have represented new shifts in Nordic nutrition policies. Political decisions have made nutritional goals an explicit part of health policy. The influence on market regulation and agricultural policy seems even more remote than previously. These two features have contributed to a closer association with the health sector, in relation to contents as well as organisation. This link seems to be strongest in Sweden, but it is evident even in the other countries.

In Finland there was an increase in the consideration given to nutrition by the Ministry for Social and Health Affairs throughout the 1980s, and by the end of the decade official recommendations to limit milk-fat consumption in 
the whole population were established (Murcott \& Prättälä, 1993). While in Norway the reformulated goals of 1975 came from the Ministry of Agriculture, in 1981 there was a new white paper from the Ministry of Health and Social Affairs, in which the link with the health sector was emphasised. This link became even more evident when nutrition was defined as part of general preventive policies in the early 1990s (Sosialdepartementet, 1981, 1992). A council of experts, primarily from within the disciplines of nutrition and medicine, later replaced the National Nutrition Council together with representatives from industry. Recently, there have been several changes and currently there is an expert-based advisory board on nutrition, along with several other similar boards, all having secretariats within the new Health Authority. In Denmark a parliamentary decision in 1989 also defined nutrition as part of health policy under the new Ministry of Health (Holm et al. 1993).

Closer links with the health sector make new types of conflicts and problems relevant. One question concerns the relationship between local independence and national strategies. Many health prevention efforts are carried out relatively autonomously within each municipality. There are a number of decision-making stages between this locally-based work, which is also to some extent carried out in collaboration with non-governmental organisations, and market regulations formulated by national and, increasingly, international bodies. Local efforts may by themselves have more influence on their specific implementation (as stated in many policy papers), but the remoteness may lead to a removal of political activity, with less organisation and less influence on overall strategic decisions.

Another question concerns the relationship between professions, a subject that is given much attention in studies of modern health policies. Until recently, the professionalisation within nutrition policy has been rather weak in the Nordic countries, compared with other areas of health or social policy. The scientific foundation is strong, but mainly developed as basic research and an integrated part of general medicine (no specialist education). The education of nutrition professionals has not been given sufficient importance (it should be regarded as a profession in its own right; Riska, 1993). Increased professionalisation in recent years may have contributed to the placement of nutrition issues higher on the agenda, and it will probably also promote a shift in the understanding of nutrition and other related fields. This situation may lead to increased specialisation and more emphasis on therapy and preventive measures, presented mainly through a focus on dietetics. However, consumers no longer consider that expert advice is unquestionable and authoritative. It is possible, therefore, that an expert-orientated strategy may be challenged, making it necessary to seek more open and active solutions in order to maintain, or regain, trust.

The shift towards the health sector is not only related to an increasing recognition of possible conflicts between goals when different policy sectors are to be coordinated. Extensive changes have taken place in market structures and agricultural policies, with international integration, deregulation and reduced subsidies, making the other Nordic countries (somewhat) more similar to the Danish system. However, this shift has not reduced the relevance of food market regulations. This issue is also still a specific objective in all the countries. In Sweden this approach was new. In the mid 1980s new political goals stated that nutrition recommendations should guide food policy. This approach represented a break with tradition, but with no objectives of effective regulation. Changes were to be achieved through educated consumer choice and voluntary product development. Voluntary symbol labelling for healthy products was introduced in 1989 (Roos et al. 2002).

However, decision-making arenas, as well as the political climate, have changed. The extensive transformation has contributed to considerable confusion in relation to food policies, where new groups have emerged as participants, in particular the consumers, and also retailers. What is now seen is renewed relevance for producerconsumer conflicts, but within new political frameworks and with demands for new political solutions. This situation is particularly evident in relation to consumer trust, where the conditions for trust between participants seem to have changed. Independence and openness have become central keywords. This shift is most visible in other areas of food policy, i.e. food safety. However, the distinction between food safety regulations and nutrition policy is not always well defined. Structural change and increased market orientation in food policy have contributed to such regulations becoming more important, and more controversial. This is also the case for nutrition-related subjects, such as labelling and product information. Consumer demands have increasingly focused on information about the origin, composition and type of production.

While conflicts related to the food market have turned out to be similar, welfare-related conflicts still show more variation. Economic distribution and social support are particularly relevant for nutrition policy in Finland, where problems of unemployment and poverty are greater than in the other countries. The importance of nutrition in welfare services has traditionally been strongest in Sweden (and to some extent also in Finland). Recent events are related to action against reductions in (what are perceived as basic) public services. In Norway the issue of nutrition has been raised mainly in discussions on insufficient meals in schools and health institutions, but without marked action and political conflict. In Denmark welfare-related conflicts still have little importance.

\section{The evidence behind the policies}

Recently, a need for evidence-based nutrition policies has been pointed out (Margetts et al. 2001). Evidence implies not only knowledge about the scientific basis of recommendations, but also about strategies that work and of policy impact. What can be said about the Nordic countries concerning the existence and use of these types of evidence?

First, Finland, Sweden and Norway have had strong and influential expert groups linked to universities dealing with nutrition, initially in medicine and physiology, but eventually also in dietary research and epidemiology. This link was evident when Nordic nutrition recommendations on fat were reformulated in 1968, made more complete in 1980, and finally revised in 1996 (Roos et al. 2002). Later, 
the Danes adopted a similar approach. In each country these experts have not only provided evidence, but (probably as important) they have been actively involved in networking, lobbying and advocacy in the development of the policy in each country (Eide, 2001). As in other Western countries, there have been numerous intervention programmes that have been rigorously evaluated, the most prominent case probably being Finland. However, the evaluations have been restricted to the duration and particular scope of each programme, thus making them of less use in discussing the formulation of the overall policy. In particular, the inter-sector nature of most nutrition policies is rarely considered, together with the general and lasting effects of the intervention programmes.

On the other hand, data relating to food consumption have been important for the feasibility and evaluation of the national nutrition policies. The strongest tradition is to be found in Norway, where annual reports on gross consumption of the basic food categories, and a nutritional evaluation of these data, have formed a cornerstone in the work of the National Nutrition Council. The Swedish Food Authority has been carrying out repeated dietary studies in various groups and in the general population over a long period of time; a process that was followed later by the other three countries (Becker, 1997). Surprisingly, however, the studies and the analyses of the data have been most concerned with mean values for the population as a whole and for demographic groups such as children or the elderly. Socio-economic variations have received much less attention, the least being shown in Norway. It is relevant, therefore, that findings show that socio-economic differences persist, perhaps even more so in Norway (Roos et al. 2002).

So, even here institutionalisation is found to influence the policy. Interest in demographic variation is linked to the physiological foundation of nutrition, focusing on physiological needs. A focus on socio-economic conditions, however, will raise questions of distribution and class, a much more controversial subject. History has shown that dealing with such conflicts will involve, or require, participation of other groups and participants. Moreover, such conflicts are not very popular at a time when concern is with individual choice rather than State regulation.

\section{The Nordic $v$. other types of nutrition policies}

Several references have been made already to the Nordic situation being an integral part of northern European development, in relation to nutrition problems, major conflicts and institutionalisation. Yet, the Nordic solution is considered to be different and more successful (Milio, 1990; Roos et al. 1997). It has been shown here that there is no single Nordic type of nutrition policy, as institutionalisation of the nutrition policies has differed considerably throughout their histories.

In welfare state research the type of welfare state in Scandinavia is compared with the British 'liberal' and the 'corporatist' continental European types of welfare state (Esping-Andersen, 1990). The liberal welfare state is characterised by means-tested assistance, modest universal transfers and social insurance plans. In turn, the State encourages market-based distribution. In corporatist welfare states the State is hesitant about market intervention, but there is a clear distinction between public and private responsibilities. The Church and a strong commitment to the preservation of the traditional family limit State interference considerably (the subsidiary principle). The traditional 'social democratic' solution is mixed. Beliefs in obtaining social welfare through market regulation are much stronger, but the intention is not to replace market distribution by bureaucracy. Decisions are commonly made as negotiated solutions, between the State and organised interests.

A very preliminary comparison indicates that these countries represent characteristically different ways of handling nutrition problems. These differences seem to be associated with the general structure of the welfare states and the relationship between State and market (U Kjærnes, unpublished results).

Quite early, UK authorities recognised nutrition as a responsibility. However, the UK seems to be the State most exposed to public criticism, in relation to both the commercial links and the lack of an acceptable social safety net. The conflict between liberalist support to market processes and health and welfare concerns has obstructed a clear attitude from the government. Despite the opportunities that were available to the State to manipulate import restrictions and subsidies on health grounds these opportunities were not taken. By and large, questions of food have remained commercial rather than related to health. The exception is found in the vulnerable sections of society, and when the market fails (Mills, 1992).

In Germany, which represents a corporatist system, the situation seems much more restrained and less controversial than in the UK. While professional recommendations have been established, implementation is relegated mainly to the very local level. The whole principle of a comprehensive nutrition policy has been neutralised on the basis of individual autonomy, making the question of responsibility very different. While some aspects point to a strengthening of this private 'solution', it may also be challenged by a general politicisation of the food issues that has been observed over the past years.

As described earlier, nutrition has been a very controversial subject in the Nordic countries, but there seems to have been general agreement that the State should do something and that efforts, typical for the region, should be universal. Thus, despite conflicts with the powerful agricultural sectors, the legitimacy of nutritional advice and its relevance for State policy has been prominent, most evidently so in Norway. Denmark represents an exception to this approach.

\section{Final comments}

In a publication on French nutrition policy Hercberg (2001) has recently stated that: 'In addition to immense human, social and economic stakes, the relationship between nutrition and health is unique in that: it concerns the entire population; it is based on thoroughly documented scientific knowledge; it involves well known risk (and protective) factors upon which it is possible to intervene; it has a considerable impact upon the incidence of the most 
frequently encountered chronic diseases; it involves the participation not only of the consumer but of all persons working in the nutritional field; and its feasibility has been demonstrated.' It can be added that this situation has been there for several decades. So why is it so difficult to establish nutrition policies, and even more difficult to establish implementation and enforcement demonstrating the political will? What can be learned from the Nordic cases?

Questions were presented in the introduction about the importance of the institutional framework for the formulation and implementation of nutrition policy. The emergence of nutrition policies in the Nordic countries shows both shared features and basic differences (Jul, 1988). Changes in the conception of nutrition problems have been quite similar, and the shifts in the understanding have taken place within about the same periods of time. There have, however, been differences in how these shifts have been expressed in relation to the participants, the intensity of the conflicts and to what extent nutrition has been defined as a social problem. Nutrition appeared on the agenda about 1900 , but it was not until the 1930s that specific public bodies were established to deal with such responsibilities. The end point was not dissimilar, with shared beliefs in knowledge developed within the traditions of hygiene and home economics (Schmidt \& Kristensen, 1986; Palmblad \& Eriksson, 1995). Hygiene did promote institutionalisation within the area of food, particularly in relation to food control, but not separate nutrition policy bodies.

The development of this independent institutional basis was linked partly to welfare policy and partly to agricultural conflicts. In simplified terms, it can be said that the welfare policy perspective dominated in Sweden, the agricultural perspective dominated in Finland, a combination of these perspectives in Norway, and neither of them in Denmark. Institutionalisation came very late in Denmark and political involvement has continued to be weak. The nature of the participating groups in the other countries did not, however, form any ideal basis for redefining the nutrition issue in the 1960s and 1970s. The process was least controversial in Sweden, where there was, at the same time, little political will for strict regulations. In Finland the redefinition was greatly impeded because of the connection with agriculture. The political interest in nutrition as part of health and welfare policy was much stronger in Norway. Even though the links to agriculture gave (potential) added support for these measures, its closed and cooperative administration created problems for the handling of the conflicts that emerged. The Danish situation, in which political will as well as measures and institutions were problematic, did, however, produce the weakest foundation. As in the other countries, the interests of the agricultural industry provide an important explanation for the weakness.

From the present discussion, it can be said that a study of Nordic nutrition policies may improve the understanding of problems associated with the relationship between welfare and health policy and market interests. When welfare policies as well as market regulation change, there will be consequences for nutrition policy, both in relation to the conditions for acceptability and trust, and to potential measures. However, this situation does not mean that nutrition policy is no longer situated in the minefield between these policy sectors.

\section{References}

Aronson N (1982) Nutrition as a social problem: A case study of entrepreneurial strategy in science. Social Problems 29, 474-487.

Becker W (1997) Utvecklingen av livsmedelskonsumptionen i Norden 1965-1994 (The development of food consumption in the Nordic countries 1965-1994). In Utfordringer i ernoeringspolitikken (Challenges in Nutrition Policy). TemaNord 1997, p. 619 [U Kjaernes, editor]. Copenhagen, Denmark.

Befolkningskommissionen (1938) Betänkande $i$ Näringsfrågan. Sveriges Offentliga Utredningar (Report on the Nutrition Issue. Swedish Public Reports) 1938:6. Stockholm, Sweden: Socialdepartementet.

Burnett J (1989) Plenty and Want. A Social History of Food in England from 1815 to the Present Day. London: Routledge.

Eide WB (2001) Breaking conceptual and methodological ground: promoting the human right to adequate food and nutrition. An example of activism with an academic base. Ecology of Food and Nutrition 40, 571-595.

Esping-Andersen G (1990) The Three Worlds of Welfare Capitalism. Cambridge: Polity Press.

Evang K \& Hansen OG (1937) Norsk Kosthold $i$ Små Hjem (The Diet Among Norwegian Poor Families). Oslo, Norway: Tiden.

Frandsen J (1937) Omkring Husholdningsraadet (About the National Council for Households). In Statens Husholdningsraad Beretning for Finansaaret 1936-37 (The National Council for Households. Report for the Financial Year 1936-37), pp. 48-58. København, Denmark: Indenrigsdepartementet

Fridericia LS (1937) Internationalt Samarbejde om Ernæringsproblemet (International Cooperation on Nutritional Problems). Statens Husholdningsraad Beretning for Finansaaret 1936-37 (The National Council for Households. Report for the Financial Year 1936-37), pp. 59-68. København, Denmark: Indenrigsministeriet.

Gustafsson B, Pihkala E \& Tønneson KD (1974) Perspektiv på den offentliga sektorn under 1930-talet (Perspectives on the Public Sector in the 1930s). Nordiska Historikermötet 1974. Mötesrapport (Nordic Meeting for Historians 1974. Meeting Report), pp. 105-153. Uppsala, Sweden: Uppsala University.

Haavet IE (1996) Maten på Bordet. 50 år Med Statens Ernaringsråd (Food on the Table. 50 Years with the National Nutrition Council). Oslo, Norway: Statens Ernæringsråd.

Hansen RI (1990) Den Hensiktsmessige Ernaringspolitikken. Prosessen Fram til Stortingsmeldingen om Norsk Ernarings- og Matforsyningspolitikk (The Appropriate Nutrition Policy. The Process Leading up to the White Paper on Norwegian Nutrition Policy). Report no. 8, Oslo, Norway: The National Institute for Consumer Research.

Helenius R (1991) Welfare society and people's health. A case study of the Finnish fat policy and its adaption to the goals of European trade integration. Politeia issue no.4, 1-30.

Helsing E (1991) Nutrition policies in Europe. Background and organization. Food Policy 16, 371-382.

Hercberg S (2001) Les bases de la politique nutritionnelle de santé publique en France: le constat et les recommendations du HCSP. Oleagineux Corps Gras Lipids 8, 7-12.

Hirdman Y (1983) Magfrågan. Mat Som Mål Och Medel Stockholm 1870-1920 (The Stomach Issue. Food as Goal and Measure. Stockholm 1870-1920). Stockholm, Sweden: Rabén \& Sjögren.

Hirdman Y (1990) Att Lägga livet Till Rätta - Studier $i$ Svensk Folkhemspolitik (To Arrange Daily Life - Studies in the Swedish Policy of People's Home). Stockholm, Sweden: Carlsson Bokförlag. 
Holm L, Bredsdorff N \& Rasmussen FD (1993) The weaknesses of nutrition policies. In Regulating Markets - Regulating People. On Food and Nutrition Policy, pp. 47-63 [U Kjærnes, editor]. Oslo, Norway: Novus Forlag.

Jensen ТØ (1993) Nutrition. A dilemma in the politics of food. In Regulating Markets - Regulating People. On Food and Nutrition Policy, pp. 17-36 [U Kjaernes, editor]. Oslo: Novus Forlag,

Jensen TØ (1994) The political history of Norwegian nutrition policy. In The Origins and Development of Food Policies in Europe, pp. 90-112 [J Burnett and DJ Oddy, editors]. London: Leicester University Press

Jensen TØ \& Kjærnes U (1997) Political dilemmas of designing the good life - The case of nutrition and social democracy. In Constructing the New Consumer Society, pp. 218-233 [J Holmwood, H Radner, G Schulze and P Sulkunen, editors]. London and New York: Macmillan.

Jones G (1986) Social Hygiene in Twentieth Century Britain. London: Croom Helm.

Jul M (1988) Mad, Ernaring og Politik i Norden. Rapport til det Permanente Nordiske Udvalg for Naringsmiddelspфrsmål (Food, Nutrition and Politics in the Nordic Countries). Uppsala, Sweden: Statens Livsmedelsverk.

Kamminga H \& Cunningham A (1995) The Science and Culture of Nutrition, 1840-1940. Amsterdam, The Netherlands and Atlanta, GA: Editions Rodopi.

Kjærnes U (1985) Spedbarns og Småbarns Erncering. En Utredning om Behov og Muligheter for Nordisk Samarbeid (The Nutrition of Infants and Young Children. A Report on the Need and Possibilities for Nordic Collaboration). Report 1985:2. Oslo, Norway: The Nordic Council of Ministers.

Kjærnes U (1990) Velferdskrav og Landbrukspolitikk. Om Framveksten av Norsk Ernoringspolitikk (Welfare Demands and Agricultural Policy. The Emergence of Norwegian Nutrition Policy). SIFO Report no. 7. Oslo, Norway: The National Institute for Consumer Research.

Kjærnes U (1996) Political struggle over scientific definitions. Nutrition as a social problem in inter-war Norwegian nutrition policy. Food, Eating, and Nutrition as Social Problems: Constructivist Perspectives, pp. 261-278 [D Maurer and J Sobal, editors]. New York: Aldine de Gruyter.

Kjærnes U (editor) (1997) Framveksten av ernæringspolitikk i Norden (The emergence of nutrition policy in the Nordic countries). Utfordringer $i$ Ernoringspolitikken (Challenges in Nutrition Policy). TemaNord 1997, pp. 73-88. Copenhagen: The Nordic Council of Ministers.

Landbruksdepartementet (1975) Om Norsk Matforsynings- og Ernaringspolitikk. Stortingsmelding (Norwegian Food Security and Nutrition Policy. White Paper) no.32 (1975-76). Oslo, Norway: Landbruksdepartementet.

Levenstein HA (1988) Revolution at the Table. The Transformation of the American Diet. New York and Oxford: Oxford University Press.

Lien M (1990) The Norwegian Nutrition and Food Supply Policy. Accomplishments and Limitations of a Structural Approach. SIFO Report no. 4. Oslo, Norway: The National Institute for Consumer Research.

Margetts B, Warm D, Yngve A \& Sjöström M (2001) Developing an evidence-based approach to Public Health Nutrition: translating evidence into policy. Public Health Nutrition 4, 1393-1397.

McDougall FL (1938) Food and welfare. League of Nations studies of nutrition and national economic policy. Geneva Studies 9, 9-56.

Milio N (1990) Nutrition Policy of Food-rich Countries. A Strategic Analysis. Baltimore, MD: The Johns Hopkins University Press.
Mills M (1992) The Politics of Dietary Change. Aldershot: Dartmouth.

Murcott A \& Prättälä R (1993) Comparing nutrition policies. A very small start. Regulating Markets, Regulating People. On Food and Nutrition Policy, pp. 37-46 [U Kjærnes, editor]. Oslo, Norway: Novus Forlag.

Myrdal G \& Myrdal A (1936) Krisen i Befolkningsspørsmålet (The Crisis in the Population Issue). Oslo, Norway: Tiden norsk Forlag.

Møller IH (1994) Velfardsstatens Udbygdning. Den Anden Socialreform 1933 (The Development of the Welfare State. The Second Social Reform 1933). Frederiksberg, Denmark: Samfundslitteratur.

Odin M (1934) Sjukdomar och Sjukdomsfrekvens i Övre Norrland Särskilt med Hänsyn til Födans Sammansättning (Diseases and Disease Incidence in Upper Norrland with Particular Focus on the Dietary Composition). Lund, Sweden: Håkan Ohlssons Boktryckeri.

Palmblad E \& Eriksson BE (1995) Kropp och Politik. Hälsoupplysning som Samfunsspägel (Body and Politics. Health Education as a Mirror of Society). Stockholm, Sweden: Carlssons Bokförlag.

Pedersen EH, Thullberg P \& Tveite S (1974) Nordens jordbruk under världskrisen 1929-1933 (Nordic Agriculture during the World Crisis 1929-1933). In Nordiska Historikermötet 1974. Mötesrapport (Nordic Meeting for Historians 1974. Meeting Point), pp. 155-206. Uppsala, Sweden: Uppsala Universitet.

Riska E (1993) The gendered character of professions in the field of nutrition. Regulating Markets, Regulating People. On Food and Nutrition Policy, pp. 171-186 [U Kjærnes, editor]. Oslo, Norway: Novus Forlag.

Roos G, Lean M \& Anderson A (1997) Dietary interventions in Finland, Norway and Sweden: Lessons from Scotland. Part I. Trends in food consumption and diet-related disease. Health Bulletin 55, 432-443.

Roos G, Lean M \& Anderson A (2002) Dietary interventions in Finland, Norway and Sweden: nutrition policies and strategies. Journal of Human Nutrition and Dietetics 15, 99-110.

Schmidt LH \& Kristensen JE (1986) Lys, Luft og Renlighed. Den Moderne Social-hygiejnes Fodsel (Light, Air and Cleanliness. The Birth of Modern Social Hygiene). København, Denmark: Akademisk Forlag.

Seip AL (1984) Sosialhjelpstaten Blir Til. Norsk Sosialpolitikk 1740-1920 (The Emergence of the Social Service State. Norwegian Social Policy 1740-1920). Oslo, Norway: Gyldendal Norsk Forlag.

Sosialdepartementet (1981) Om Oppfølging av Norsk Ernaringspolitikk. Stortingsmelding nr.11 (1981-82) (The Follow-up of Norwegian Nutrition Policy. White Paper no.11 (1981-82)). Oslo, Norway: Sosialdepartementet.

Sosialdepartementet (1992) Utfordringer i Helsefremmende og Forebyggende Arbeid. Stortingsmelding nr.37 (1992-93) (Challenges in Health Promotion and Prevention. White Paper no. 37, 1992-93)). Oslo, Norway: Sosialdepartementet.

Statens Husholdningsraad (1937) Beretning for Finansaaret 1936-37 (Report on the Financial Year 1936-37). København, Denmark: Indenrigsministeriet.

Steinmo S, Thelen K \& Longstreth F (1992) Structuring Politics. Historical Institutionalism in Comparative Analysis. Cambridge: Cambridge University Press.

Zebich ML (1979) The politics of nutrition: issue definition, agenda-setting, and policy formulation in the United States. Dissertation, University of New Mexico, Albuquerque, USA. 